\title{
Domestic violence against pregnant women: A prospective study in a metropolitan city, İstanbul
}

\author{
Hüseyin Cengiz, Ammar Kanawati, Şükrü Yıldız, Sema Süzen, Tuba Tombul \\ Department of Obstetrics and Gynecology, Bakirköy Dr. Sadi Konuk Teaching and Research Hospital, İstanbul, Turkey
}

\section{Abstract}

Objective: Violence against women, particularly against pregnant women, is increasingly being recognized as a significant problem around the world. Limited studies were found about domestic violence among pregnant women. The aim of this study was to determine the prevalence of domestic violence during pregnancy and the factors affecting it.

Material and Methods: This prospective study was conducted at the Department of Obstetrics and Gynecology, between January 2012 and April 2013. A total of 1349 pregnant women, irrespective of age and socioeconomic status, were interviewed using a questionnaire in the local language.

Results: The incidence of domestic violence in this study was $2.37 \%$. The mean age of women who reported violence was $29.06 \pm 5.53$ years. Age, marriage duration, gravidity, parity, educational level, partner's educational level, and monthly income exerted no significant influences on women who experienced domestic violence during their pregnancies $(\mathrm{p}>0.05)$. Women who resided in the same houses with large extended families were at significantly higher risk of domestic violence during pregnancy in comparison with the pregnant women who lived within a core family $(\mathrm{p}=0.018)$.

Conclusion: Domestic violence during pregnancy is a potential public health problem. Education, improvements in economic autonomy, and society's attitudes may reduce domestic violence. Health-care providers should increase their awareness of risk factors to protect women from domestic violence. (J Turk Ger Gynecol Assoc 2014; 15: 74-7)

Key words: Abuse, domestic violence, pregnant women, Turkey

Received: 30 July, 2013

Accepted: 15 October, 2013

\section{Introduction}

Violence against women, particularly against pregnant women, is increasingly being recognized as a significant problem around the world (1). Studies conducted in various countries have indicated that domestic violence against pregnant women varies between $4-40 \%(2,3)$. Domestic violence exerts serious adverse effects. It has been reported that domestic violence has been associated with miscarriages, premature births, low birth weights, defective antenatal care, early placental separations, membrane ruptures, and fetal injuries $(4,5)$. In Turkey, pregnancy is the major reason why women enter health-care facilities. However, health-care providers generally remain unaware of domestic violence and do not take an interest in this problem.

There is a lack of robust data in Turkey on the prevalence of domestic violence during pregnancy. Only a limited number of studies that are focused on domestic violence during pregnancy have been conducted in Turkey. Therefore, our goal was to determine the prevalence of domestic violence during pregnancy, the factors affecting it, and the relationship between women's social status and domestic violence.

\section{Material and Methods}

This cross-sectional survey of pregnant women's experience with domestic violence was conducted in the antenatal ward of our clinic, between January 2012 and April 2013. Ethical approval was obtained from the institutional review board. Istanbul is the largest city in Turkey. It has a population of 13.9 million people. The city is one of the largest urban areas in Europe. It is the second largest city in the world with respect to urban populations. High numbers of immigrants travel from eastern and southeastern Turkey to Istanbul. Immigrants have cultural characteristics similar to general Eastern cultural characteristics. All pregnant women who attended the antenatal clinic at the participating health facility were eligible for the study. Participants were selected by simple random sampling performed on clinic days. Women who were too ill or had obstetric emergencies were excluded. The admitted pregnant women were interviewed by a clinic nurse in complete privacy. Informed consents were obtained, and interviews were conducted using a specific questionnaire. The questionnaire included questions that referred to physical violence when women were slapped, pushed, hit with a fist, choked, or threatened and sexual violence when women 
reported that they were forced to have some form of sexual intercourse. To assess intimate partner violence, women were asked: Has your husband/partner threatened you verbally, slapped you, pulled your hair, kicked you, or thrown you to the ground. A "yes" to any of these options was coded 1 versus 0 when none of these was reported. Types of abuse were defined as verbal and physical. Verbal violence included the use of degrading sentences, blaming, and swearing. Slapping, hitting, pushing, throwing women against walls, pulling hair, kicking, brandishing knives, and causing other injuries were classified as physical violence. Interview durations ranged between 30 minutes and 1 hour. Research assistants were trained on the importance of maintaining confidentiality. All women who were identified as at risk for violence were referred for counseling and further support.

SPSS 21.0 for Windows ${ }^{\circledR}$ software (Chicago, IL, USA) was used to conduct a statistical analysis of the data. Means, standard deviations, and percentages were used to evaluate descriptive statistics. The distribution of variables was controlled by the Kolmogorov-Smirnov test. The Mann-Whitney U-test was used to conduct a quantitative data analysis. Associations were tested using $\chi^{2}$ or Fisher's exact test, as appropriate. The level of statistical significance was set at $\mathrm{p}<0.05$.

\section{Results}

In total, 1349 pregnant patients were included in the study. Out of the total study population, $2.37 \%(n=32)$ reported they were victims of violence during their pregnancies. The mean age of women who reported violence was $29.06 \pm 5.53$ years. The mean gravidity was $2.78 \pm 1.54$. The mean parity was $1.34 \pm 1.18$. Almost all participants (99\%) were married, 49.9\% had achieved educational levels of primary school or lower, 1104 (81.8\%) were housewives, $10.4 \%$ smoked cigarettes, and none used alcohol. The results revealed that $47 \%$ of pregnant women's partners had graduated from preliminary school, $38.1 \%$ had graduated from high school, and 9.2\% had earned bachelor's degrees.

Age, marriage duration, gravidity, parity, educational level, partner's educational level, and monthly income exerted no significant influences on women who experienced domestic violence during their pregnancies ( $p>0.05)$. Women who resided in the same houses with large extended families were at significantly higher risk of domestic violence during pregnancy in comparison with the pregnant women who lived within a core family $(p=0.018)$. Table 1 shows the comparisons of the profiles of women who experienced violence during their pregnancies before they became pregnant with women who had not experienced violence. Remarkably, almost $30.5 \%$ of the women had unplanned pregnancies. However, this factor did not exert any influence on whether these women experienced violence during their pregnancies $(\mathrm{p}>0.05)$.

\section{Discussion}

Domestic violence (intimate partner or family violence) against women is a significant public health problem because of its prevalence, as well as because of its short- and long-term physical and mental health consequences (6). Violence during pregnancy demands special attention, because it affects women in a moment of great physical and emotional vulnerability. It has also been associated with adverse obstetric or neonatal outcomes, such as low birth weight and preterm delivery. Over both the short term and long term, physical injuries affect family life, which has a significant effect on children and loss of faith and trust in the institution of the family. These results not only affect the quality of life of individuals and society but also have long-term effects on social order. In a study focused on 290 pregnant women, Helton and Snodgrass (7) discovered a $15 \%$ prevalence of physical abuse prior to pregnancy and an additional 8\% prevalence during current pregnancies. In the largest series conducted by Amaro et al. (8), they discovered a $7 \%$ prevalence of violence during current pregnancies. Hillard (9), Stewart (10), and Campbell (11) discovered a similar prevalence of violence during pregnancy (4\%, 6.6\%, and $8.2 \%$, respectively). In the present study, we discovered a $2.37 \%$ prevalence of violence during pregnancy. In a study conducted in eastern Turkey, Arslantaş et al. (12) discovered an $18.2 \%$ prevalence of physical violence, and Taşpınar et al. (13) also discovered a $24.8 \%$ prevalence of violence. A report published by the National Research on Domestic Violence Against Women in Turkey stated that the number of women who suffered from violence during pregnancy varied based on geographic regions (14). Generally, women's social status was worse in the eastern region. Despite high immigration rates, we were surprised to discover a low prevalence of violence (2.37\%) in comparison with Western countries. We believe that pregnant women exposed to violence were afraid to disclose their experiences. They were afraid of their husbands, even if their husbands remained outside the clinic. In all likelihood, pregnant victims would hesitate to speak about violence, even in a tertiary center, and it is possible they might more easily disclose their experiences in first-line health-care units. It can be difficult to compare the differing results for the prevalence of violence, because women's understanding of the definition of violence may differ. These differences might be related to social norms. Some reports have noted that women who experience physical violence during pregnancy tend to be younger $(10,15)$. We were unable to discover any differences related to age. It has been well documented that women's exposure to violence tends to be lower among women who possess higher education levels (16-18). We achieved inconclusive results for educational levels in comparison with previous reports. However, we discovered a significant difference in the relationship between the number of people who resided together in the same house and exposure to violence. As the number of people who resided in the same house increased, the likelihood of exposure to violence also increased. In Turkey, some girls and boys continue to marry because they are pressured by their families and/or relatives. These couples continue to reside with their relatives after getting married. Turkish legal regulations state that any verbal or physical act of violence will be punished. However, women must lodge complaints against perpetrators. Unfortunately, women fail to make complaints because they 
Table 1. Comparison of characteristics of women who experienced violence during their pregnancies with women who did not experience violence

\begin{tabular}{|c|c|c|c|c|c|c|}
\hline & & & ixposure & ence & & \\
\hline & & & & & $\mathrm{D} / \mathrm{n} \%$ & $p$ value \\
\hline Frequency of violence (monthly) & & & & & & \\
\hline Gravidity & & & & & & 0.086 \\
\hline Parity & & & & & & 0.053 \\
\hline Number of children & & & & & & 0.078 \\
\hline Marriage duration (years) & & & & & & 0.514 \\
\hline Age (years) & & & & & 5.53 & 0.383 \\
\hline Marital status & No & 4 & $0.3 \%$ & 0 & $0.0 \%$ & 1000 \\
\hline & Yes & 1.313 & $99.7 \%$ & 32 & $100.0 \%$ & 1.000 \\
\hline & None & 100 & $7.6 \%$ & 4 & $12.5 \%$ & \\
\hline & Primary school & 555 & $42.1 \%$ & 15 & $46.9 \%$ & \\
\hline Women's educational status & Secondary school & 217 & $16.5 \%$ & 2 & $6.3 \%$ & 0.189 \\
\hline & High School & 351 & $26.7 \%$ & 11 & $34.4 \%$ & \\
\hline & University & 94 & $7.1 \%$ & 0 & $0.0 \%$ & \\
\hline Women's work status & Unemployed & 1.078 & $81.9 \%$ & 26 & $81.3 \%$ & \\
\hline & Employed & 239 & $18.1 \%$ & 6 & $18.8 \%$ & 0.930 \\
\hline Partners' educational status & Primary school and below & 616 & $46.8 \%$ & 19 & $59.4 \%$ & \\
\hline & High School & 617 & $46.9 \%$ & 12 & $37.5 \%$ & 0.342 \\
\hline & University & 83 & $6.3 \%$ & 1 & $3.1 \%$ & \\
\hline Income/month & 500 Dollars and below & 679 & $51.6 \%$ & 17 & $53.1 \%$ & \\
\hline & 500-1000 Dollars & 474 & $36.0 \%$ & 10 & $31.3 \%$ & 0.422 \\
\hline & 1000-1500 Dollars & 84 & $6.4 \%$ & 1 & $3.1 \%$ & \\
\hline & 1500 Dollars and above & 80 & $6.1 \%$ & 4 & $12.5 \%$ & \\
\hline Householder & Rental & 704 & $53.5 \%$ & 18 & $56.3 \%$ & 0754 \\
\hline & Own & 613 & $46.5 \%$ & 14 & $43.8 \%$ & 0.107 \\
\hline $\begin{array}{l}\text { Number of people residing } \\
\text { together in house }\end{array}$ & & & & & & 0.018 \\
\hline Systemic illness & No & 1.166 & $88.5 \%$ & 31 & $96.9 \%$ & 0.140 \\
\hline & Yes & 151 & $11.5 \%$ & 1 & $3.1 \%$ & \\
\hline Smoking & No & 1.180 & $89.6 \%$ & 29 & $90.6 \%$ & 0851 \\
\hline & Yes & 137 & $10.4 \%$ & 3 & $9.4 \%$ & 0.001 \\
\hline Planned pregnancy & No & 398 & $30.2 \%$ & 14 & $43.8 \%$ & 0101 \\
\hline & Yes & 919 & $69.8 \%$ & 18 & $56.3 \%$ & \\
\hline Gestational week & & & & & 3.82 & 0.569 \\
\hline Coital frequency per week & & & & & & 0.469 \\
\hline Contraception & No & 440 & $33.4 \%$ & 10 & $31.3 \%$ & 0.798 \\
\hline & Yes & 877 & $66.6 \%$ & 22 & $68.8 \%$ & \\
\hline History of unplanned pregnancy & No & 54 & $6.2 \%$ & 4 & $15.4 \%$ & 0082 \\
\hline & Yes & 811 & $93.8 \%$ & 22 & $84.6 \%$ & \\
\hline
\end{tabular}


fear discrimination or further exposure to violence perpetrated primarily by men. Turkish social customs contribute to females' poor self-esteem. In some areas, society excuses violence against women. In our study, with the exception of one case, all perpetrators were husbands. In the exceptional case, the perpetrator was the woman's father-in-law. Khosla et al. (19) reported that $51.8 \%$ of women in their study experienced violence perpetrated by their husbands' families.

The current study was limited, because it employed a small number of subjects. In addition, the current study's results solely reflect a small area of Turkey. Additional larger studies are required to evaluate the risk factors for violence during pregnancy. Researchers should interview men to determine risk factors and reasons for the perpetration of violence against women.

In conclusion, domestic violence during pregnancy is a potential public health problem. Education and improvements in economic autonomy and society's attitudes may reduce domestic violence. Health-care providers should increase their awareness of risk factors to protect women from domestic violence.

Ethics Committee Approval: Ethics committee approval was received for this study from Bakırköy Dr. Sadi Konuk Research Hospital.

Informed Consent: Written informed consent was obtained from patients who participated in this study.

Peer-review: Externally peer-reviewed.

Author contributions: Concept - H.C.; Design - H.C., A.K.; Supervision - H.C.; Resource - H.C., S..Y.; Materials - H.C., S..Y., S.S.; Data Collection\&/or Processing - A.K., S.S.; Analysis\&/or Interpretation - H.C., S.Y.; Literature Search - H.C., S..Y.; Writing H.C., S.Y.; Critical Reviews - S..Y.

Conflict of Interest: No conflict of interest was declared by the authors.

Financial Disclosure: The authors declared that this study has received no financial support.

\section{References}

1. Granja AC, Zacaria E, Bergstron S. Violent deaths: The hidden face of maternal mortality. BJOG 2002; 109: 5-8. [CrossRef]

2. Johnson JK, Haider F, Ellis K, Hay DM, Lindow SW. The prevalence of domestic violence against pregnant women. BJOG 2003; 110: 272-5. [CrossRef]
3. Ventura CS, Ventura MS, Drengsted-Nielsen S, Johansen KS. Domestic abuse in a central Mediterranean pregnant population. Eur J Obstet Gynecol Reprod Biol 2001; 98: 3-8. [CrossRef]

4. Sharps PW, Koziol-McLain J, Campbell J, McFarlane J, Sachs C, Xu X. Health care providers' missed opportunities for preventing femicide. Prev Med 2001; 33: 373-80. [CrossRef]

5. Wiebe ER, Janssen P. Universal screening for domestic violence in abortion. Womens Health Issues 2001; 11: 436-41. [CrossRef]

6. Escribà-Agüir V, Ruiz-Pérez I, Saurel-Cubizolles MJ. Screening for domestic violence during pregnancy. J Psychosom Obstet Gynaecol 2007; 28: 133-4. [CrossRef]

7. Helton AS, Snodgrass SC. Battering during pregnancy: intervention strategies. Birth 1987; 14: 142-7. [CrossRef]

8. Amaro H, Fried LE, Cabral H, Zucherman B. Violence during pregnancy and substance use. Am J Public Health 1990; 80: 575-9. [CrossRef]

9. Hillard PA. Physical abuse in pregnancy. Obstet Gynaecol 1985; 66: 185-190.

10. Stewart DE, Ceccutti A. Physical abuse in pregnancy. CMAJ 1993; 149: 1257-63.

11. Campbell JC, Poland ML, Walter JB, Anger J. Correlates of battering during pregnancy. Res Nurs Health 1992; 15: 219-26. [CrossRef]

12. Arslantas H, Adana F, Ergin F, Gey N, Biçer N, Kiransal N. Domestic violence during pregnancy in an eastern city of Turkey: a field study. J Interpers Violence 2012; 27: 1293-313. [CrossRef]

13. Taşpınar A, Bolsoy N, Şirin A. Gebeler fiziksel şiddete uğruyorlar mı? Manisa örneği. Adli Psikiyatri Dergisi 2005; 2: 41-7.

14. Turkish Republic Prime Ministry Directorate General on the Status of Women. Domestic violence against women in Turkey. 2009.

15. Gielen AC, O'Campo PJ, Faden RR, Kass NE, Xue X. Interpersonal conflict and physical violence during the childbearing years. Soc Sci Med 1994; 39: 781-7. [CrossRef]

16. Abasiubong F, Abasiattai AM, Bassey EA, Ogunsemi OO. Demographic risk factors in domestic violence among pregnant women in Uyo, a community in the Niger Delta Region, Nigeria. Health Care Women Int 2010; 31: 891-901. [CrossRef]

17. Okyay P, Ergin F, Evci ED, Bilgen MA, Önde M, Beşer E. Prevalence and risk factors of domestic violence against married women and their attitude toward violence. 12th World Congress on Public Health-Making a Difference in Global Public Health: Education, Research and Practice, İstanbul. 2009.

18. Yanıkkerem E, Karadaş G, Adigüzel B, Sevil U. Domestic violence during pregnancy in Turkey and responsibility of prenatal healthcare providers. Am J Perinatol 2006; 23: 93-103. [CrossRef]

19. Khosla AH, Dua D, Devi L, Sud SS. Domestic violence in pregnancy in North Indian women. Indian J Med Sci 2005; 59: 195-9. [CrossRef] 